\title{
Glutamine metabolism in chick enterocytes: absence of pyrroline-5-carboxylase synthase and citrulline synthesis
}

\author{
Gouyao WU, Nick E. FLYNN, Wene YAN and Douglas G. BARSTOW, Jr. \\ Department of Animal Science and Faculty of Nutrition, Texas A\&M University, College Station, TX 77843-2471, U.S.A.
}

This study was designed to determine whether pyrroline-5carboxylate (P-5-C) synthase is deficient in chick enterocytes therefore resulting in the lack of synthesis of ornithine and citrulline from glutamine. Post-weaning pig enterocytes, which are known to contain P-5-C synthase and to synthesize both ornithine and citrulline from glutamine, were used as positive controls. Enterocytes were incubated at $37^{\circ} \mathrm{C}$ for $0-30 \mathrm{~min}$ in the presence of $2 \mathrm{mM}\left[\mathrm{U}-{ }^{14} \mathrm{C}\right]$ glutamine or $2 \mathrm{mM}$ ornithine plus $2 \mathrm{mM} \mathrm{NH}_{4} \mathrm{Cl}$. In chick enterocytes, glutamine was metabolized to $\mathrm{NH}_{3}, \mathrm{CO}_{2}$, glutamate, alanine and aspartate, but not to ornithine, citrulline, arginine or proline. Likewise, there was no formation of citrulline, arginine, alanine or aspartate from ornithine in chick enterocytes. Furthermore, the rate of conversion of ornithine into proline in chick enterocytes was only about $4 \%$ of that in cells from pigs. To elucidate the reason for the inability of chick enterocytes to synthesize ornithine and citrulline from glutamine, the activities of the enzymes involved were measured. No activity of P-5-C synthase or ornithine carbamoyltransferase was found in chick enterocytes, in contrast with cells from postweaning pigs. It was also demonstrated that the activity of ornithine aminotransferase in chick enterocytes was only $3 \%$ of that in cells from pigs. Thus the present findings elucidate the biochemical reason for the lack of endogenous synthesis of ornithine and citrulline in chicks. Our results also explain previous observations that ornithine cannot replace arginine or proline in the diet of chicks. We suggest that the absence of P-5$C$ synthase and ornithine carbamoyltransferase in enterocytes is the metabolic basis for the nutritional requirement of arginine in the chick.

\section{INTRODUCTION}

Arginine has been known to be an essential amino acid for chicks for more than 50 years [1]. A series of Tamir and Ratner [2,3] demonstrated that arginine can be synthesized from citrulline, but not from ornithine, in chicks, because of the presence of argininosuccinate synthase (ASS; EC 6.3.4.5) and argininosuccinate lyase (ASL; EC 4.3.2.1) in kidneys and certain other organs such as pancreas, spleen and intestine. Although these findings satisfactorily explain the classical observations that citrulline, but not ornithine, can replace arginine in the diet of chicks $[1,4]$, the mechanism for the lack of endogenous synthesis of ornithine or citrulline in the chick remains unknown. The inability of the chick to synthesize ornithine, citrulline and arginine has previously been attributed to the absence of four of the hepatic urea-cycle enzymes [carbamoyl phosphate synthase I (CPS I; EC 6.3.4.16), ornithine carbamoyltransferase (OCT; EC 2.1.3.3), ASS and ASL], in contrast with the mammalian counterpart with an active urea cycle [2,3]. This view, however, may be incorrect, in the light of our current understanding of endogenous arginine synthesis which involves the conversion of intestinederived citrulline into arginine in the cells of the proximal convoluted kidney tubule [5-8].

Ornithine is synthesized from glutamate via the formation of pyrroline-5-carboxylate (P-5-C) in rat small intestinal mucosa $[9,10]$. It is noteworthy that glutamate is produced from glutamine (the most abundant free amino acid in plasma) by phosphatedependent glutaminase (PDG; EC 3.5.1.2) [11], underscoring an important role of glutamine in intestinal ornithine and citrulline synthesis. This notion is further supported by our recent findings on the formation of ornithine and citrulline from glutamine in post-weaning pig enterocytes [12]. It is now known that the synthesis of citrulline from glutamine involves PDG, P-5-C synthase, ornithine aminotransferase (OAT; EC 2.6.1.13) and OCT, in addition to CPS I for the provision of carbamoyl phosphate (Scheme 1). All these enzymes are located in mitochondria [9-11], and this compartmentation plays an important role in substrate channelling in the synthesis of citrulline from glutamine in enterocytes.

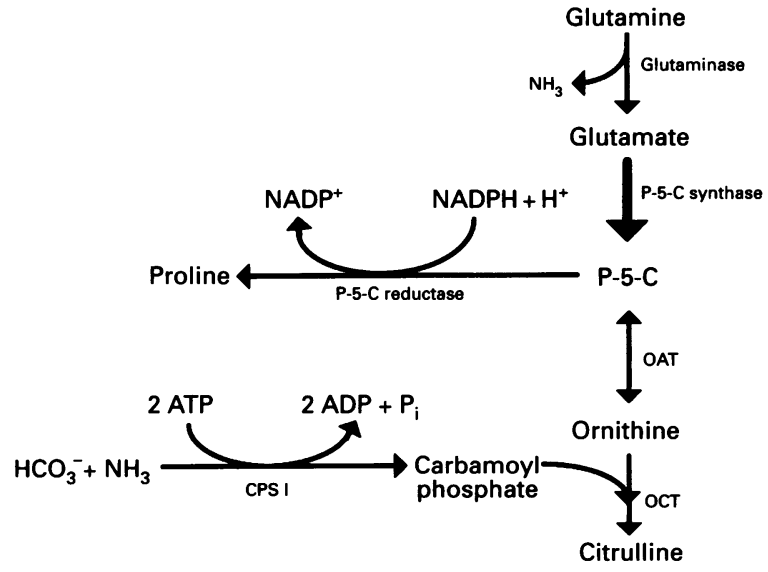

Scheme 1 Citrulline synthesis from glutamine in enterocytes

Abbreviations used: ASL, argininosuccinate lyase; ASS, argininosuccinate synthase; AS, argininosuccinate; CPS, carbamoyl phosphate synthase; OCT, ornithine carbamoyltransferase; OAT, ornithine aminotransferase; PDG, phosphate-dependent glutaminase; P-5-C, pyrroline-5-carboxylate; $\mathrm{KHB}$, Krebs-Henseleit bicarbonate.

* To whom all correspondence should be addressed. 
We and others have suggested that $\mathrm{P}-5-\mathrm{C}$ synthase is the major regulatory enzyme in the synthesis of ornithine and citrulline from glutamine in enterocytes [10,12]. In this regard, it is noteworthy that $\mathrm{P}-5-\mathrm{C}$ synthase has been reported to be deficient in the intestinal mucosa of the cat [13] which, although possessing all hepatic urea-cycle enzymes, cannot synthesize arginine, an essential amino acid for this species [14]. We hypothesize that P-5-C synthase is deficient in or absent from enterocytes of the chick, which results in its inability to synthesize ornithine and citrulline from glutamine. The present study was designed to test this hypothesis. Post-weaning pig enterocytes, which are known to contain P-5-C synthase activity and to synthesize ornithine and citrulline from glutamine [12], were used as positive controls.

\section{MATERIALS AND METHODS}

\section{Chemicals}

L-Glutamine, L-citrulline, L-ornithine, D-glucose, $\mathrm{NH}_{4} \mathrm{Cl}$, BSA (fraction V, essentially fatty acid-free), Hepes, P-S-C, OCT, and Nonidet P40 were purchased from Sigma Chemical Co. (St. Louis, MO, U.S.A.). Glutamate dehydrogenase, 2-oxoglutaric acid, $\beta$-NADH and ADP were obtained from BoehringerMannheim (Indianapolis, IN, U.S.A.). H.p.l.c.-grade methanol and water were from Fisher Scientific (Houston, TX, U.S.A.). L$\left[\mathrm{U}-{ }^{14} \mathrm{C}\right]$ Glutamate and $\mathrm{L}_{-}\left[\mathrm{U}-{ }^{14} \mathrm{C}\right]$ glutamine came from American Radiolabeled Chemicals (St. Louis, MO, U.S.A.). P-5-C was purified using a column $(0.6 \mathrm{~cm} \times 7 \mathrm{~cm})$ of Dowex AG 1 (X8 resin; acetate form) (Bio-Rad, Richmond, CA, U.S.A.) as previously described [15]. Briefly, P-5-C was loaded into the resin column, which was washed with $7.5 \mathrm{ml}$ of water followed by elution of P-5-C with $7.5 \mathrm{ml}$ of $25 \mathrm{mM}$ acetic acid.

\section{Chicks and pigs}

Male White-Leghorn chicks (35 days old; $386 \pm 15 \mathrm{~g}$; mean \pm SEM, $n=6)$ and 35 -day-old male pigs $(7.6 \pm 0.3 \mathrm{~kg}$; mean \pm SEM, $n=6$ ) were obtained from the Poultry and Swine Centers of Texas A\&M University. Pigs were offspring of Yorkshire $\times$ Landrace sows and Duroc $\times$ Hampshire boars, and had previously been weaned at the age of 21 days. Chicks and weaned pigs were fed on corn/soyabean-meal-based diets containing $22 \%$ and $21 \%$ protein respectively, meeting U.S. National Research Council requirements of all nutrients [16,17].

\section{Isolation of jejunum from chicks and pigs}

After the chicks had been anaesthetized with $\mathrm{CO}_{2}$ and killed by cervical dislocation, jejunum $(50 \mathrm{~cm})$ was dissected out. Pig jejunum $(50 \mathrm{~cm})$ was obtained as described by $\mathrm{Wu}$ et al. [12]. The experiments were carried out in accordance with the guidelines of the U.S. National Research Council for the care and use of animals, and were approved by Texas A\&M University's Animal Care Committee.

\section{Preparation and incubation of enterocytes}

Enterocytes were prepared from chick and pig jejunum, using oxygenated $\left(\mathrm{O}_{2} / \mathrm{CO}_{2}, 19: 1\right) \mathrm{Ca}^{2+}$-free Krebs-Henseleit bicarbonate (KHB) buffer supplemented with $5 \mathrm{mM}$ EDTA, as previously described $[12,18]$. The viability of isolated enterocytes was greater than $90 \%$, as assessed by Trypan Blue exclusion [12] and by the measurement of lactate dehydrogenase activity in both the incubation medium $(2 \mathrm{ml})$ and enterocytes at the end of the $30 \mathrm{~min}$ incubation period [18]. Cell viability was also confirmed by measurement of $\mathrm{O}_{2}$ consumption using a YSI model
5300 Biological Oxygen Monitor consisting of Clark-type polarographic oxygen probes, four sample chambers and a circulatory water bath, as described by $\mathrm{Wu}$ et al. [12].

Incubations were performed at $37^{\circ} \mathrm{C}$ in $25 \mathrm{ml}$ polypropylene conical flasks placed in a shaking water bath (70 oscillations/ $\mathrm{min}$ ). Cells (4-5 mg of protein $/ \mathrm{ml}$ ) were incubated for $0,10,20$ and $30 \mathrm{~min}$ in the presence of $2 \mathrm{ml}$ of $\mathrm{KHB}$ buffer ( $\mathrm{pH} \mathrm{7.4;}$ saturated with $\left.\mathrm{O}_{2} / \mathrm{CO}_{2}, 19: 1\right)$ containing $10 \mathrm{mM}$ Hepes, $1 \%$ BSA and $5 \mathrm{mM}$ glucose. The medium also contained 0 or $2 \mathrm{mM}$ [U-14 C]glutamine (150 d.p.m./nmol) or $2 \mathrm{mM}$ ornithine plus $2 \mathrm{mM} \mathrm{NH}_{4} \mathrm{Cl}$. The gas phase in the flask was $\mathrm{O}_{2} / \mathrm{CO}_{2}, 19: 1$. Incubations were initiated by addition of cells and terminated by addition of $0.2 \mathrm{ml}$ of $1.5 \mathrm{M} \mathrm{HClO}{ }_{4} \cdot{ }^{14} \mathrm{CO}_{2}$ was collected in Hyamine hydroxide and its radioactivity measured in a Beckman liquid-scintillation counter [12]. Neutralized cell extracts were used for measurement of metabolites, as described below.

\section{Measurement of metabolites}

Amino acids including arginine, citrulline, ornithine, aspartate and alanine in neutralized cell extracts were quantified by a fluorimetric h.p.l.c. method involving precolumn derivative formation with $o$-phthaldialdehyde [12]. Protine was determined as 4-amino-1-butanol by an h.p.l.c. method as described by Wu [19]. $\mathrm{NH}_{3}$ was determined using an enzymic method involving glutamate dehydrogenase and 2-oxoglutarate [20].

\section{Measurement of the activities of enzymes involved in citrulline synthesis from glutamine}

Enterocytes were suspended in KHB buffer, and cell extracts were prepared by three cycles of freezing in liquid nitrogen and thawing at $37^{\circ} \mathrm{C}$. The supernatants obtained after centrifugation $(13000 \mathrm{~g} ; 1 \mathrm{~min})$ were used for assay of PDG, OAT, OCT and CPS I at $37^{\circ} \mathrm{C}$ for $15 \mathrm{~min}$ as described by Wu et al. [12]. Briefly, the assay mixture $(0.2 \mathrm{ml})$ for PDG contained $20 \mathrm{mM}$ glutamine, $150 \mathrm{mM}$ potassium phosphate buffer $(\mathrm{pH} 8.2)$ and cell extract $(0.1 \mathrm{mg}$ of protein). The assay mixture $(2 \mathrm{ml})$ for OAT consisted of $75 \mathrm{mM}$ potassium phosphate buffer ( $\mathrm{pH} 7.5), 20 \mathrm{mM}$ ornithine, $0.45 \mathrm{mM}$ pyridoxal phosphate, $3.75 \mathrm{mM}$ 2-oxoglutarate, $5 \mathrm{mM} o$-aminobenzaldehyde and cell extract ( $1 \mathrm{mg}$ of protein). The assay mixture $(0.2 \mathrm{ml})$ for OCT contained $0.1 \mathrm{M}$ potassium phosphate buffer (pH 7.5), $20 \mathrm{mM}$ ornithine, $10 \mathrm{mM}$ carbamoyl phosphate and cell extract ( $0.3 \mathrm{mg}$ of protein). The assay mixture $(0.5 \mathrm{ml})$ for CPS I consisted of $0.15 \mathrm{M}$ potassium phosphate buffer (pH 7.5), $25 \mathrm{mM}$ ATP, $25 \mathrm{mM} \mathrm{MgCl}_{2}, 5 \mathrm{mM} \mathrm{N}$-acetylglutamate, $10 \mathrm{mM} \mathrm{NH}_{4} \mathrm{Cl}, 5 \mathrm{mM}$ ornithine, $5 \mathrm{mM} \mathrm{NaHCO}$ and 10 units of OCT.

Enterocyte extracts prepared by freezing and thawing at $37^{\circ} \mathrm{C}$ were not used for P-5-C synthase assay because this enzyme is known to be heat-labile [10]. Instead, mitochondria were prepared from enterocytes at $4{ }^{\circ} \mathrm{C}$, lysed with Nonidet P40 (a detergent) and used to measure $\mathrm{P}-5-\mathrm{C}$ synthase activity by a sensitive radiochemical method involving $\left[\mathrm{U}-{ }^{14} \mathrm{C}\right]$ glutamate as recommended by Kramer et al. [15]. The assay mixture ( $1 \mathrm{ml})$ consisted of $0.1 \mathrm{M}$ Hepes ( $\mathrm{pH} 7.4$ ), $20 \mathrm{mM} \mathrm{MgCl}, 1 \mathrm{mM}$ gabaculine (an inhibitor of OAT), $1 \mathrm{mM}\left[\mathrm{U}-{ }^{14} \mathrm{C}\right]$ glutamate $\left(10^{3}\right.$ d.p.m. $\left./ \mathrm{nmol}\right)$, $3 \mathrm{mM}$ ATP, $0.2 \mathrm{mM}$ NADPH, $15 \mathrm{mM}$ phosphocreatine, 10 units of creatine kinase, $0.25 \%$ Nonidet $\mathrm{P} 40$ and mitochondria $\left(0.6 \mathrm{mg}\right.$ of protein). After incubation at room temperature $\left(22^{\circ} \mathrm{C}\right)$ for $30 \mathrm{~min}$, the assay medium was acidified with $100 \mu \mathrm{l}$ of $1.5 \mathrm{M}$ $\mathrm{HClO}_{4}$, and neutralized with $40 \mu \mathrm{l}$ of $2 \mathrm{M} \mathrm{K}_{2} \mathrm{CO}_{3}$. Neutralized extracts were used for separation of $\left[{ }^{14} \mathrm{C}\right] \mathrm{P}-5-\mathrm{C}$ using Dowex AG $1(\times 8)$ resin as previously described $[12,15]$, with the recovery of P-5-C being $99.5 \%$, as determined with purified P-5-C standard. Mitochondria, but not enterocyte extracts, were used for P-5-C 
synthase assay, because of potential conversion of P-5-C into proline by cytosolic P-5-C reductase [10].

\section{Measurement of the activities of ASS, ASL and argininase}

The activities of ASS, ASL and arginase were measured as described by Dhanakoti et al. [8], except that the products were quantified by a sensitive fluorimetric h.p.l.c. method [12]. The ASS assay mixture $(0.2 \mathrm{ml})$, which consisted of $75 \mathrm{mM}$ potassium phosphate buffer ( $\mathrm{pH} 7.5$ ), $10 \mathrm{mM}$ citrulline, $10 \mathrm{mM}$ aspartate, $5 \mathrm{mM}$ ATP and cell lysate ( $0.4 \mathrm{mg}$ of protein), was incubated at $37^{\circ} \mathrm{C}$ for 0 or $20 \mathrm{~min}$. The incubation was terminated by addition of $50 \mu \mathrm{l}$ of $1.5 \mathrm{M} \mathrm{HClO}_{4}$. Neutralized extracts were used for analysis of argininosuccinate (AS) and arginine by h.p.l.c. using precolumn derivative formation with $o$-phthaldialdehyde [12], with the retention time of AS and arginine being 6.7 and $27.2 \mathrm{~min}$ respectively. The sum of AS and arginine was used to indicate ASS activity, because some AS $(<10 \%)$ was converted into arginine as the result of the presence of ASL in the cell extracts. The ASL assay mixture $(40 \mu \mathrm{l})$, which contained 129 $\mathrm{mM}$ sodium phosphate buffer ( $\mathrm{pH} 7.0$ ), $20 \mathrm{mM}$ AS and $65 \mathrm{mM}$ EDTA, was incubated at $37^{\circ} \mathrm{C}$ for 0 or $15 \mathrm{~min}$. The incubation was terminated by addition of $20 \mu l$ of $1.5 \mathrm{M} \mathrm{HClO}_{4}$, and neutralized extracts were used for arginine analysis by h.p.l.c. [12] to indicate ASL activity. For the assay of arginase (EC 3.5.3.1), a mixture of $50 \mu \mathrm{l}$ of $100 \mathrm{mM} \mathrm{MnCl}_{2}$ and $50 \mu \mathrm{l}$ of cell lysate $\left(0.5 \mathrm{mg}\right.$ of protein) was incubated at $55^{\circ} \mathrm{C}$ for $5 \mathrm{~min}$. After cooling to room temperature, the mixture was incubated with $50 \mu 1$ of $30 \mathrm{mM}$ arginine (in $150 \mathrm{mM}$ potassium phosphate buffer, $\mathrm{pH} 7.5$ ) at $37^{\circ} \mathrm{C}$ for 0 or $10 \mathrm{~min}$. The incubation as terminated by addition of $50 \mu \mathrm{l}$ of $1.5 \mathrm{M} \mathrm{HClO}_{4}$, and neutralized extracts were used for ornithine analysis by h.p.l.c. [12].

\section{Determination of protein and expression of data}

Protein in enterocytes, cell lysates and mitochondria was determined by a modified Lowry method with BSA as standard [21]. Data are expressed on the basis of protein content in the enterocytes, cell extracts or mitochondria (P-5-C synthase) as indicated in the Table. It was established in preliminary experiments that all enzyme assays were linear with time and the amount of cell protein used.

\section{Statistical analysis}

Data, given as means \pm S.E.M., were analysed by one-way analysis of variance with the Student-Newman-Keuls multiple comparison test for identification of significant differences among mean [22]. Probability values less then 0.05 were taken to indicate statistical significance.

\section{RESULTS AND DISCUSSION}

\section{Blochemical viability of incubated chick enterocytes}

The rat of glutamine metabolism in incubated enterocytes is related to the biochemical viability of the cells, which depends, to a significant extent, on the animal species used. Watford et al. [18] reported that enterocytes isolated from chicks remain viable for a longer period of time than do cells from rats, on the basis of linear $\mathrm{O}_{2}$ consumption during the $60 \mathrm{~min}$ incubation period. In the present study, we found that $\mathrm{O}_{2}$ consumption by chick enterocytes in the presence of $2 \mathrm{mM}$ glutamine plus $5 \mathrm{mM}$ glucose was linear for at least $30 \mathrm{~min}$, and was $21.5 \pm 1.4$, $94.0 \pm 4.6, \quad 196 \pm 13, \quad 308 \pm 19, \quad 412 \pm 24, \quad 503 \pm 33, \quad$ and $621 \pm 29 \mathrm{nmol} / \mathrm{mg}$ of protein at the end of $1,5,10,15,20,25$ and
$30 \mathrm{~min}$ incubation periods respectively $(n=6)$. In the presence of $5 \mathrm{mM}$ glucose, the production of $\mathrm{CO}_{2}, \mathrm{NH}_{3}$, glutamate, alanine and aspartate from $2 \mathrm{mM}$ glutamine at the end of 10,20 and $30 \mathrm{~min}$ incubation periods ( $\mathrm{nmol} / \mathrm{mg}$ of protein) was $24.6 \pm 2.1$, $51.3 \pm 2.8$ and $78.9 \pm 3.3\left(\mathrm{CO}_{2}\right), 14.0 \pm 1.7,28.3 \pm 3.6$ and $40.3 \pm 4.1\left(\mathrm{NH}_{3}\right), 5.1 \pm 0.4,9.8 \pm 0.7$ and $14.9 \pm 0.87$ (Glu), $3.8 \pm 0.3, \quad 7.8 \pm 0.6$ and $12.2 \pm 0.11$ (Ala) and $0.76 \pm 0.05$, $1.58 \pm 0.12$ and $2.21 \pm 0.16$ (Asp) respectively $(n=6)$. Taken together, our data on the linearity of $\mathrm{O}_{2}$ consumption and production of glutamine metabolites by chick enterocytes during the $30 \mathrm{~min}$ incubation period indicate the biochemical viability of these cells under the experimental conditions used.

\section{Production of $\mathrm{CO}_{2}, \mathrm{NH}_{3}$, glutamate, alanine and aspartate from glutamine in chick enterocytes}

The major products of glutamine in chick enterocytes were $\mathrm{CO}_{2}$, $\mathrm{NH}_{3}$, glutamate, alanine and aspartate (Table 1), as reported for rat [18] and pig [12] enterocytes. Our data, which are consistent with those of Watford et al. [18] for chick enterocytes, are in contrast with the findings of Porteous [23] who reported that there was no significant formation of either $\mathrm{NH}_{3}$ or aspartate from glutamine $(2.5 \mathrm{mM})$ in the presence of $5 \mathrm{mM}$ glucose in these cells. The rates of glutamine utilization were found to be similar to those of $\mathrm{NH}_{3}$ production in chick enterocytes (Table 1), indicating that the glutamate formed from glutamine is converted into 2-oxoglutarate mainly via transamination to produce alanine and aspartate. This pattern of glutamine metabolism in chick enterocytes is similar to that observed in tumour cells [24], fibroblasts [24], macrophages [25] and lymphocytes [20].

\section{Lack of synthesis of ornithine, clitrulline and arginine from glutamine in chick enterocytes}

To the best of our knowledge, there are no published data on citrulline synthesis or the activities of citrulline-synthesizing enzymes in chick enterocytes. This is due to the lack of study of the role of the intestine in citrulline synthesis in the chick $[2,3]$. However, in the light of our recent understanding of the small intestine as the major source of citrulline for renal arginine synthesis [5-8,12], it is important to determine whether ornithine and citrulline are synthesized from glutamine in chick enterocytes and to elucidate the mechanism involved.

There was no measurable ornithine or citrulline in chick enterocytes (the detection limit of our fluorimetric h.p.l.c. method for these two amino acids was $50 \mathrm{pmol} / \mathrm{ml}$ of medium) in the presence or absence of $2 \mathrm{mM}$ glutamine plus $5 \mathrm{mM}$ glucose, indicating the lack of synthesis of ornithine and citrulline from glutamine in these cells. These results are in contrast with those of Porteous [23] who used a much less sensitive u.v./visible amino acid analyser than our fluorimetric h.p.l.c. method was able to observe the formation of ornithine from $2.5 \mathrm{mM}$ glutamine plus $5 \mathrm{mM}$ glucose in chick enterocytes. Although this discrepancy is not understood at present, our failure to detect production of ornithine and citrulline from glutamine in chick enterocytes was unlikely to be due to an artifact. This conclusion is based on our observations that, under the same experimental conditions, ornithine and citrulline were produced from $2 \mathrm{mM}$ glutamine in the presence of $5 \mathrm{mM}$ glucose by enterocytes of 29-58-day-old post-weaning pigs [12]. Likewise, no arginine was synthesized from glutamine in chick enterocytes on the basis of (i) arginine concentrations in cell extracts between the presence and absence of $2 \mathrm{mM}$ glutamine (Table 1) and (ii) the measurement of $\left[{ }^{14} \mathrm{C}\right]$ arginine by a sensitive radiochemical method involving arginase and urease [26]. The possibility that conversion 


\section{Table 1 Glutamine metabolism in chick enterocytes}

Enterocytes were prepared from the jejunum of 35 -day-old chicks, and were incubated at $37^{\circ} \mathrm{C}$ for $30 \mathrm{~min}$ in $2 \mathrm{ml}$ of $\mathrm{KHB}$ buffer (pH 7.4) containing $5 \mathrm{mM}$ glucose. The medium also contained $2 \mathrm{mM}\left[\mathrm{U}^{-14} \mathrm{C}\right]$ glutamine or $2 \mathrm{mM}$ ornithine plus $2 \mathrm{mM} \mathrm{NH}_{4} \mathrm{Cl}\left(\mathrm{Orn}_{\mathrm{rNH}}{ }^{+}\right)$. Data are means \pm S.E.M. $(n=6)$. Means with different superscripts within a column are significantly different $(P<0.05)$, as analysed by one-way analysis of variance with the Student-Newman-Keuls multiple comparison test. None indicates that no substrates were added to the incubation medium.

\begin{tabular}{|c|c|c|c|c|c|c|c|c|}
\hline \multirow{2}{*}{$\begin{array}{l}\text { Addition } \\
\text { to } \\
\text { medium }\end{array}$} & \multirow{2}{*}{$\begin{array}{l}\text { Gln } \\
\text { utilization }\end{array}$} & \multicolumn{7}{|c|}{ Metabolites in cell extracts ( $\mathrm{nmol} / \mathrm{mg}$ of protein after $30 \mathrm{~min}$ incubation) } \\
\hline & & $\mathrm{CO}_{2}$ & $\mathrm{NH}_{3}$ & Glu & Ala & Asp & $\operatorname{Arg}$ & Pro \\
\hline $\begin{array}{l}\text { None } \\
\text { Orn/ } / \mathrm{NH}_{4}{ }^{+} \\
\mathrm{Gln}\end{array}$ & $\begin{array}{l}- \\
- \\
35.9 \pm 4.1\end{array}$ & $\begin{array}{l}- \\
\overline{78.9 \pm 3.3}\end{array}$ & $\begin{array}{l}18.3^{\mathrm{a}} \pm 2.4 \\
- \\
36.3^{\mathrm{b}} \pm 6.7\end{array}$ & $\begin{array}{l}12.9^{\mathrm{a}} \pm 1.1 \\
12.4^{\mathrm{a}} \pm 1.0 \\
24.9^{\mathrm{b}} \pm 2.3\end{array}$ & $\begin{array}{l}14.1^{\mathrm{a}} \pm 0.77 \\
13.8^{\mathrm{a}} \pm 1.05 \\
23.2^{\mathrm{b}} \pm 0.72\end{array}$ & $\begin{array}{l}3.71^{\mathrm{a}} \pm 0.26 \\
3.43^{\mathrm{a}} \pm 0.27 \\
5.18^{\mathrm{b}} \pm 0.28\end{array}$ & $\begin{array}{l}5.39 \pm 0.33 \\
5.11 \pm 0.42 \\
5.13 \pm 0.26\end{array}$ & $\begin{array}{l}2.18^{\mathrm{a}} \pm 0.36 \\
3.56^{\mathrm{b}} \pm 0.54 \\
2.24^{\mathrm{a}} \pm 0.30\end{array}$ \\
\hline
\end{tabular}

of citrulline into arginine and its subsequent hydrolysis to urea and ornithine by arginase may account for the absence of measurable citrulline or net arginine synthesis can be ruled out, because the activities of ASS, ASL and arginase were low or negligible in chick enterocytes: $0.15 \pm 0.02,0.22 \pm 0.03$ and $0.34 \pm 0.06 \mathrm{nmol} / \mathrm{min}$ per $\mathrm{mg}$ of protein respectively $(n=6)$. Note that the activities of ASS, ASL and arginase in 35-day-old post-weaning pig enterocytes were $1.72 \pm 0.24,3.01 \pm 0.29$ and $2.28 \pm 0.35 \mathrm{nmol} / \mathrm{min}$ per $\mathrm{mg}$ of protein respectively $(n=6)$, which were about 5-10-fold greater than those in chick enterocytes. As a result, we were not able to detect the formation of urea from glutamine in chick enterocytes even using the sensitive fluorimetric enzymic method involving urease and glutamate dehydrogenase [27].

To provide a metabolic basis for the inability of chick enterocytes to synthesize ornithine or citrulline from glutamine, the activities of PDG, P-5-C synthase, OAT, OCT and CPS I were measured in chick enterocytes. The activity of CPS I in chick enterocytes was $1.27 \pm 0.06 \mathrm{nmol}$ of $\mathrm{CP} / \mathrm{min}$ per $\mathrm{mg}$ of protein) $(n=6)$, which is similar to that in cells from 29-58-dayold post-weaning pigs [12]. The activities of PDG and OAT in chick enterocytes were $1.95 \pm 0.37$ and $1.42 \pm 0.39 \mathrm{nmol} / \mathrm{min}$ per mg of protein respectively $(n=6)$, which are only about $17 \%$ and $3 \%$ of those in cells from 29-58-day-old pigs [12]. The low activity of glutaminase in chick enterocytes may explain, at least, in part, our observations that the rate of glutamine utilization was 5-fold lower in these cells (Table 1) than in pig enterocytes [12]. Interestingly, no activity of P-5-C synthase or OCT could be found in chick enterocytes even by sensitive radiochemical or fluorimetric h.p.l.c. methods respectively. When P-5-C synthase was measured at $20^{\circ} \mathrm{C}$ in the presence of $20 \%$ glycerol, which was found to stabilize rat intestinal P-5-C synthase [10], we were still unable to detect any activity in chick enterocytes. It is unlikely that our failure to detect P-5-C synthase and OCT activities in chick enterocytes resulted from artifacts in enzyme assays, on the basis of our findings that P-5-C synthase $(357 \pm 28 \mathrm{pmol} / \mathrm{min}$ per $\mathrm{mg}$ of protein, $n=6)$ and OCT [12] were consistently found to be present in pig enterocytes. Thus it is evident that the activities of citrulline-synthesizing enzymes (except CPS I) were generally much lower in chick than in pig enterocytes, and that the absence of either P-5-C synthase or OCT itself is sufficient to account for the lack of ornithine and citrulline synthesis from glutamine in chick enterocytes.

Taken together, our findings provide, for the first time, a reason for the absence of synthesis of ornithine and citrulline from glutamine in chick enterocytes. We suggest that the absence of P-5-C synthase of OCT from enterocytes, but not that of hepatic urea-cycle enzymes, results in the lack of endogenous synthesis of ornithine or citrulline from glutamine in chicks, as reported for cats [13]. This view is in contrast with that of Tamir and Ratner [2,3] who attributed the lack of endogenous arginine synthesis in the chick to the absence of CPS I, OCT, ASS and ASL in the liver. Thus, although citrulline can be converted into arginine in the kidneys and certain other organs of the chick [2,3], the lack of endogenous synthesis of citrulline from glutamine in enterocytes offers a new explanation for the well-documented observation that arginine is an essential amino acid for this species $[1,4]$.

\section{Lack of proline synthesis from glutamine in chick enterocytes}

In the present study, we were not able to demonstrate synthesis of proline from $2 \mathrm{mM}$ glutamine in the presence of $5 \mathrm{mM}$ glucose in chick enterocytes (Table 1). Our data are consistent with those of Watford et al. [18] and Porteous [23] for chick enterocytes incubated in the presence of $5 \mathrm{mM}$ glutamine plus $10 \mathrm{mM}$ glucose and $2.5 \mathrm{mM}$ glutamine plus $5 \mathrm{mM}$ glucose respectively. We suggest that this lack of proline synthesis from glutamine in chick enterocytes resulted from the absence of P-5-C synthase for conversion of glutamate into $\mathrm{P}-5-\mathrm{C}$, the common precursor of both ornithine and proline [28]. On the basis of the accumulation of proline in cell extracts at the end of incubation, Porteous [23] concluded that proline was formed from glutamine $(2.5 \mathrm{mM})$ in chick enterocytes incubated in the absence of glucose. However, it should be noted that similar amounts of proline also accumulated in the extracts of chick enterocytes incubated in the absence of glutamine or any other substrates [23]. Thus it is possible that the accumulation of proline in the incubation medium of chick enterocytes incubated in the presence of glutamine $(2.5 \mathrm{mM})$ alone [23] might have resulted from the net degradation of intracellular protein rather than the synthesis of proline from glutamine.

\section{Lack of synthesis of citrulline and arginine from ornithine and a low rate of conversion of ornithine into proline in chick enterocytes}

Ornithine has been shown to be ineffective at replacing arginine [4] or proline [29] in the diet of chicks. However, the mechanism involved remains unknown. Likewise, little is known about ornithine metabolism in chick enterocytes. It is noteworthy that the conversion of ornithine into arginine and proline involves the formation of citrulline and P-5-C by OCT and OAT respectively (Scheme 1). Because of the lack of P-5-C synthase in the liver, kidney and cell types other than intestinal mucosa and thymocytes of rats, the small intestine has been suggested to be the major organ for proline synthesis in this species [11,28]. 
There was no conversion of ornithine into citrulline and arginine in chick enterocytes (Table 1), which is consistent with the absence of OCT from these cells. These findings are in contrast with those for pig enterocytes [12]. Likewise, there was no formation of glutamate, alanine or aspartate from ornithine in chick enterocytes (Table 1). Furthermore, the rate of conversion of ornithine into proline in chick enterocytes (Table 1) was only $4 \%$ of that in cells from 29-58-day-old pigs [12]. These findings are consistent with the lack of OAT in chick enterocytes for converting ornithine into $\mathrm{P}-5-\mathrm{C}$, the common precursor of both glutamate and proline (Scheme 1) [28]. It is noteworthy that the activity of OAT is particularly high in rat intestinal mucosa [9] and pig enterocytes [12] for as yet unknown reasons. To the best of our knowledge, this is the first report of the deficiency of OAT in chick enterocytes which is associated with a known metabolic consequence in this species. Thus, in pig enterocytes, the high activity of OAT facilitated the conversion of ornithine into P-5-C, which was then utilized for the synthesis of glutamate and proline (Scheme 1). Glutamate was subsequently converted into alanine and aspartate via transamination. Because of the negligible metabolism of ornithine and $\mathrm{NH}_{3}$ by chick enterocytes, there was no measurable utilization of either substrate $(2 \mathrm{mM}$ each) by these cells, on the basis of their disappearance from the incubation medium.

It is evident from the above that the absence of OCT and deficiency in OAT is sufficient to account for the lack of ornithine metabolism in chick enterocytes. Our findings are of nutritional and physiological importance, as they provide, for the first time, a metabolic basis for previous observations that ornithine is an ineffective replacement of arginine [4] or proline [29] in the diet of chicks.

In conclusion, the inability to synthesize ornithine and citrulline from glutamine in chick enterocytes resulted from the absence of P-5-C synthase and OCT from these cells. Our findings elucidate further the biochemical mechanism for the nutritional requirement for arginine in the chick. Moreover, the deficiency of OAT limited the conversion of ornithine into proline and glutamate in chick enterocytes. These data provide a metabolic basis for the inability of ornithine to replace arginine and proline in the diet of chicks.

We thank Dr. Malcolm Watford for invaluable advice on enterocyte preparation and helpful discussion. The dissection of pig jejunum by Dr. Darrell A. Knabe, the provision of chicks by Dr. Christopher A. Bailey and the secretarial support of Mrs. Collysue Lawson are gratefully acknowledged. This research was supported by competitive grants no. 92-37206-8004 and 94-37206-1100 from the United States Department of Agriculture and a Hatch project no. 8200 from the Texas Agricultural Experiment Station (all to G. W.).

\section{REFERENCES}

1 Klose, A. A., Stokstad, E. L. R. and Almquist, H. J. (1938) J. Biol. Chem. 123, $691-698$

2 Tamir, H. and Ratner, S. (1963) Arch. Biochem. Biophys. 102, 249-258

3 Tamir, H. and Ratner, S. (1963) Arch. Biochem. Biophys. 102, 259-269

4 Klose, A. A. and Almquist, H. J. (1940) J. Biol. Chem. 135, 153-155

5 Fetherston, W. R., Rogers, Q. R. and Freedland, R. A. (1973) Am. J. Physiol. 224, 127-129

6 Windmueller, H. G. and Spaeth, A. E. (1981) Am. J. Physiol. 241, E473-E480

7 Dhanakoti, S. N., Brosnan, J. T., Herzberg, G. R. and Brosnan, M. E. (1990) Am. J. Physiol. 259, E437-E442

8 Dhanakoti, S. N., Brosnan, M. E., Herzberg, G. R. and Brosnan, J. T. (1990) Biochem. J. 282, 369-375

9 Henslee, J. C. and Jones, M. E. (1982) Arch. Biochem. Biophys. 219, 186-197

10 Walabayashi, Y., Henslee, J. G. and Jones, M. E. (1983) J. Biol. Chem. 258, 3873-3882

11 Windmueller, H. G. (1982) Adv. Enzymol. Relat. Areas Mol. Biol. 53, 201-237

12 Wu, G., Knabe, D. A. and Flynn, N. E. (1994) Biochem. J. 299, 115-121

13 Rogers, Q. R. and Phang, J. M. (1985) J. Nutr. 115, 146-150

14 Morris, J. G. and Rogers, Q. R. (1978) J. Nutr. 108, 1944-1953

15 Kramer, J. J., Henslee, J. G., Wakabayashi, Y. and Jones, M. E. (1985) Methods Enzymol. 113, 113-120

16 National Research Council (1984) Nutrient Requirements of Poultry (8th revision), National Academy Press, Washington, D.C.

17 Wu, G., Borbolla, A. G. and Knabe, D. A. (1994) J. Nutr. 124, 2437-2444

18 Watford, M., Lund, P. and Krebs, H. A. (1979) Biochem. J. 178, 589-596

19 Wu, G. (1993) J. Chromatogr. 641, 168-175

20 Wu, G., Field, C. J. and Marliss, E. B. (1991) Biochem. J. 274, 49-54

21 Markwell, M. A. L., Haas, S. M., Bieber, L. L. and Tolbert, N. E. (1978) Anal. Biochem. 87, 206-210

22 Steel, R. G. D. and Torrie, J. H. (1980) Principles and Procedures of Statistics, McGraw-Hill, New York

23 Porteous, J. W. (1980) Biochem. J. 188, 619-632

24 Kovacevic, Z. and McGivan, J. D. (1983) Physiol. Rev. 63, 547-605

25 Wu, G., Field, C. J. and Marliss, E. B. (1991) Biochim. Biophys. Acta 1115, 166-173

26 Wu, G. and Brosnan, J. T. (1992) Biochem. J. 281, 45-48

27 Brock, A., Chapman, S. A., Ulman, E. A. and Wu, G. (1994) J. Nutr. 124, 340-344

28 Jones, M. E. (1985) J. Nutr. 115, 509-515

29 Graber, G. and Baker, D. H. (1971) Proc. Soc. Exp. Biol. Med. 138, 585-588 